\title{
Korelasi antara Motivasi Belajar dengan Prestasi Belajar Matematika Kelas V SD Negeri Jatisarono Nanggulan Kulon Progo Tahun Ajaran 2018/2019
}

\author{
Edy Wahyu Wibowo \\ Universitas Nahdlatul Ulama Yogyakarta \\ edywahyuwibowo@unu-jogja.ac.id
}

\section{Sejarah Artikel}

diterima 20/01/2020

\begin{abstract}
The purpose of this study was to determine the correlation of learning motivation and mathematics learning achievement. This study is a quantitative research. The subject of the study was all grade five students of Jatisarono Elementary School. Questionnaires and documentation were used to collect the data. The validity was done using product moment formula, while the reliability of the data tested using alpha formula. Prerequisite analysis of the data was applied with normality and linearity test. Hypothesis test of the study was analyzed using product moment correlation. The result of the data analysis showed that $r$ count is higher than $r$ table with $N=20$ in the level of significance of $5 \%$, that is $0,493>0,360$. The conclusion of this research is that there are positive and significant correlation between learning motivation and learning achievement of Mathematics lesson in grade five Jatisarono Elementary School. Keywords: Motivation, Leaning Achievement, Mathematics
\end{abstract}

\section{Abstrak}

Tujuan penelitian ini adalah untuk mengetahui hubungan motivasi belajar dengan prestasi belajar Matematika. Penelitian ini merupakan jenis penelitian deskriptif kuantitatif. Subjek penelitian adalah seluruh peserta didik kelas V SD Negeri Jatisarono. Metode penelitian menggunakan angket dan dokumentasi. Uji validitas menggunakan rumus product moment dan uji reliabilitas menggunakan rumus alpha. Uji prasyarat analisis melalui uji normalitas dan linearitas. Pengujian hipotesis menggunakan analisis korelasi product moment. Hasil analisis diperoleh harga $r$ hitung lebih besar dari harga $r$ tabel dengan $\mathrm{N}=20$ pada taraf signifikansi $5 \%$, yaitu $0,493>0,360$. Simpulan penelitian ini adalah terdapat hubungan positif dan signifikan antara motivasi belajar dengan prestasi belajar pada mata pelajaran Matematika kelas V SD Negeri Jatisarono.

Keywords: Motivasi, Prestasi Belajar, Matematika 


\section{PENDAHULUAN}

Pendidikan menjadi salah satu kebutuhan primer manusia saat ini untuk menghadapai disrupsi di era revolusi industri 4.0. Pendidikan merupakan kunci untuk membuka cakrawala pengetahuan dimana pendidikan disini memiliki fungsi untuk mengembangkan kemampuan/ potensi, minat dan bakatyang ada di dalam dirinya. Hal tersebut seuai dengan tujuan pendidikan nasional yang dituangkan dalam UU No. 20 Tahun 2003 Pasal 3 Tentang Sistem Pendidikan Nasional, yaitu: "Pendidikan Nasional berfungsi mengembangkan kemampuan dan membentuk watak serta peradaban bangsa yang bermartabat dalam rangka mencerdaskan potensi peserta didik agar menjadi manusia yang beriman dan bertaqwa kepada Tuhan Yang Maha Esa, berakhlak mulia, sehat, berilmu, cakap kreatif dan menjadi warga Negara yang demokratis serta bertanggung jawab".

Hal ini berarti bahwa pendidikan menempati posisi yang sangat penting dan sangat krusial untuk memajukan perkembangan suatu bangsa. Tujuan pendidikan yang tertuang dalam Sisdiknas di atas akan tercapai apabila ada keterlibatan secara aktif dan penuh tanggungjawab, dari semua pihak, baik dari peserta didik, orang tua, guru, pemerintah, lembaga pedidikan serta masyarakat.

Guru dalam melakukan proses pembelajaran di sekolah meliputi proses perencanaan, proses pelaksanaan, dan proses evaluasi. Dalyono (2012: 55) berpendapat bahwa berhasil atau tidaknya seseorang guru dalam proses pembelajaran disebabkan oleh beberapa faktor yang mempengaruhi pencapaian prestasi belajar yaitu faktor internal dan faktor eksternal. Faktor internal meliputi kesehatan, intelegensi dan bakat, motivasi, minat dan cara belajar. Kemudian faktor eksternal meliputi lingkungan keluarga, sekolah, masyarakat, dan lingkungan sekitar peserta didik.

Prestasi belajar merupakan hasil akhir dari proses belajar. Hal ini sejalan dengan pendapat Winkel (Hamdu dan Agustina, 2011: 92) yang menyebutkan bahwa "prestasi belajar merupakan bukti keberhasilan belajar atau kemampuan peserta didik dalam melakukan kegiatan belajar sesuai dengan bobot yang dicapainya". Dengan kata lain prestasi belajar merupakan keberhasilan peserta didik dalam mencapai tujuan pembelajaran. Keberhasilan peserta didik dalam mencapai tujuan pembelajaran dapat dilihat melalui tiga ranah pengetahuan yaitu kognitif, psikomotor, dan afektif. Hal tersebut sesuai dengan taksonomi yang dikemukakan oleh Bloom (Sudjana, 2009: 22-23) menyatakan bahwa prestasi belajar dapat dicapai melalui tiga ranah, yaitu: kognitif, afektif, dan psikomotor

Rendahnya prestasi belajar yang dicapai oleh peserta didik dipengaruhi oleh beberapa faktor. Salah satu faktor yang sangat berpengaruh terhadap rendahnya prestasi belajar adalah faktor internal yaitu motivasi dalam belajar. Bakar (2014: 723) berpendapat bahwa "Motivation is a complex part of human psychology and behavior that influences how individuals choose to invest their time, how much energy they exert in any given task, how they think and feel about the task, and how long they persist at the task". Motivasi khususnya motivasi dalam belajar merupakan dorongan internal dan 
eksternal pada peserta didik yang sedang belajar untuk melakukan proses perubahan tingkah laku. Sejalan dengan pendapat di atas Mc. Donald (Kompri, 2016: 229) juga berpendapat bahwa motivasi adalah perubahan energi dalam diri seseorang yang ditandai dengan munculnya afektif atau perasaan (feeling) dan reaksi untuk mencapai tujuan.

Tiga elemen penting yang terkandung dalam pengertian motivasi yang dikemukakan oleh Mc. Donald di atas, yaitu:

a.Motivasi merupakan awal dari terjadinya sebuah perubahan pada diri setiap individu/ peserta didik.

b. Motivasi muncul dengan ditandai munculnya rasa atau "feeling", afektif seseorang.

c. Motivasi dirangsang karena adanya sebuah tujuan. Jadi motivasi merupakan respons dari suatu aksi yaitu tujuan.

Sehingga dapat disimpulkan bahwa peserta didik yang memiliki motivasi belajar yang tinggi akan mempunyai dorongan untuk mengikuti kegiatan pembelajaran. Hal ini tentu akan berdampak positif pada peserta didik yaitu mencapai prestasi belajar yang optimal.

Terdapat beberapa mata pelajaran dasar yang ada ditingkat pendidikan sekolah dasar salah satunya yaitu mata pelajaran matematika. Hal ini sejalan dengan Depdiknas (Susanto, 2013: 184) yang menyatakan bahwa matematika merupakan salah satu bidang studi yang hamper selalu ada dan diajarkan di semua jenjang pendidikan dari tingkat sekolah dasar sampai dengan perguruan tinggi, bahkan secara informal juga diajarkan di Taman Kanak-kanak (TK).
Mata pelajaran matematika ditingkat sekolah dasar sangatlah penting karena pada jenjang inilah penanaman konsep-konsep dasar matematika di ajarkan. Konsepkonsep tersebut dapat membantu peserta didik dalam menyelesaikan permasalahan dalam kehidupan sehari-hari dan juga mengembangkan kesadaran tentang nilai-nilai secara esensial. Hal ini sejalan dengan pendapat Susanto (2013: 185) yang menyatakan bahwa matematika merupakan disiplin ilmu yang dapat meningkatkan kemampuan berfikir, berargumentasi, memberikan kontribusi dalam penyelesaian masalah sehari-hari dan memberikan dukungan untuk pengembangan ilmu pengetahuan dan teknologi.

Fakta yang terjadi di lapangan, peserta didik usia sekolah dasar beranggapan bahwa materi mata pelajaran matematika sangat sulit. Hal ini sesuai dengan hasil penelitian yang dilakukan oleh Siregar (2017: 224) yang menyatakan bahwa sebanyak $45 \%$ siswa mempersepsikan matematika cukup sulit, dan sebanyak $80 \%$ siswa mengatakan matematika merupakan pelajaran yang penting. Hal ini lebih dipertegas lagi dengan pendapat Supardi dan Leonard (2020: 342) yang menyatakan siswa cenderung menganggap matematika sebagai pelajaran yang membosankan dan menakutkan karena penuh angka dan rumus.

Hasil pengamatan di lapangan dan wawancara kepada guru kelas $\mathrm{V}$ SD Negeri Jatisarono Nanggulan, ditemukan bahwa masih banyak permasalahan-permasalahan yang berkaitan dengan prestasi belajar peserta didik khususnya pada mata pelajaran matematika. Rendahnya minat/ motivasi peserta didik dalam belajar khususnya pada mata 
pelajaran matematika ini tampak dari kurangnya semangatnya peserta didik dalam mengikuti proses pembelajaran di kelas, kemudian rendahnya keterlibatan peserta didik dalam aktivitas pembelajaran, serta kurangnya minat peserta didik terhadap kegiatan pembelajaran.

Hasil observasi awal juga menunjukkan bahwa masih banyak peserta didik yang malas mengikuti kegiatan belajar mengajar di kelas. Terdapat peserta didik yang kurang serius dalam mengikuti kegiatan pembelajaran, sehingga berakibat tidak memahami materi pelajaran. Banyak peserta didik yang berada di dalam kelas hanya membuat kegaduhan, diantaranya lebih memilih bermain dengan teman sebangkunya, bahkan tidak jarang juga ditemukan peserta didik yang bermalas-malasan atau mengantuk di dalam kelas.

Berdasarkan hasil dari identifikasi permasalahan di lapangan maka dalam penelitian ini akan dibatasi permasalahan yang akan diteliti yaitu pada hubungan motivasi belajar dengan prestasi belajar matematika. Sehingga tujuan dalam penelitian ini adalah untuk mengetahui adakah hubungan motivasi belajar dengan prestasi belajar matematika kelas V SD Negeri Jatisarono, Kecamatan Nanggulan, Kabupaten Kulon Progo tahun ajaran 2018/2019.

\section{METODE}

\section{a. Jenis Penelitian}

Jenis penelitian ini adalah penelitian kuantitatif. Penelitian ini termasuk ke dalam jenis penelitian kuantitatif karena data penelitiannya berupa skor atau nilai, yang kemudian dianalisis menggunankan statistik untuk menjawab pertanyaan atau hipotesis penelitian. Hal ini sesuai dengan pendapat Sugiyono (2003: 14) yang menyatakan bahwa penelitian kuantitatif, adalah penelitian dengan memperoleh data yang berbentuk angka atau data kualitatif yang diangkakan.

\section{b. Subjek Penelitian}

Subjek dalam penelitian ini adalah seluruh peserta didik kelas V SD Negeri Jatisarono, Kecamatan Nanggulan, Kabupaten Kulon Progo pada tahun ajaran 2018/2019. Dengan jumlah peserta didik adalah 20 peserat didik. Dalam penelitian ini, didik dan dokumentasi nilai peserta didik semester gasal kelas $V$ SD peneliti tidak mengambil sampel akan tetapi menggunakan seluruh populasi sebagai subjek penelitian yaitu 20 peserta didik.

\section{c. Variabel Penelitian}

Variabel dalam penelitian ini terdiri dari dua variabel yaitu variabel bebas $(X)$ dan variabel terikat $(Y)$. Variabel bebas dalam penelitian ini adalah motivasi belajar perserta didik. Sedangkan varibel terikat dalam penelitian ini adalah prestasi belajar peserta didik pada mata pelajaran matematika.

\section{d. Teknik dan Instrumen Pengumpulan Data}

Teknik pengumpulan data yang digunakan dalam penelitian ini adalah angket/ kuesioner dan dokumentasi. Kemudian instrumen pengumpulan data adalah angket motivasi peserta

Negeri Jatisarono Nanggulan Kulon Progo. 
Penyusunan angket dalam modifikasi skala Likert adalah sebagai penelitian ini menggunakan skala berikut.

Likert yang telah dimodifikasi. Hasil

Tabel 1.

Skor Jawaban Angket

\begin{tabular}{lc}
\hline \multicolumn{1}{c}{ Pilihan } & Skor \\
\hline $\mathrm{A}=$ Selalu & 4 \\
$\mathrm{~B}=$ Sering & 3 \\
$\mathrm{C}=$ Kadang-Kadang & 2 \\
$\mathrm{D}=$ Tidak Pernah & 1 \\
\hline
\end{tabular}

\section{e. Teknik Analisis Data}

Analisis data dalam penelitian ini digunakan untuk mengetahui dan menggambarkan mengenai keadaan kedua variabel, yaitu variabel motivasi belajar dan prestasi belajar

Penggambaran dua variabel ini dinyatakan dalam bentuk prosentase yang selanjutnya akan ditafsirkan dengan tabel kriteria menurut Azwar Matematika peserta didik kelas V SD. (2010: 109) sebagai berikut.

Tabel 2.

Kriteria motivasi Belajar

\begin{tabular}{c|c}
\hline Skala & Kategori \\
\hline$X>\mu+1,0 \sigma$ & Tinggi \\
$\mu-1,0 \sigma<X \leq \mu+1,0 \sigma$ & Sedang \\
$X \leq \mu-1,0 \sigma$ & Rendah \\
\hline
\end{tabular}

\section{f. Uji Hipotesis}

Untuk menguji hipotesis dalam Dari hasil nilai $r$ (koefisien korelasi) penelitian ini digunakan rumus yang telah dihitung, dapat diketahui Pearson Product Moment (Arikunto, ada tidaknya korelasi dan besarnya 2006: 170) sebagai berikut:

$$
r_{\mathrm{xy}}=\frac{N \sum X Y-\left(\sum X\right)\left(\sum Y\right)}{\left.\sqrt{\left\{\sum X^{2}-\left(\sum X\right)^{2}\right\}\left\{N \sum Y^{2}-\left(\sum Y\right)^{2}\right.}\right\}}
$$
korelasi. Sedangkan interpretasi nilai $r$ menurut Sugiyono (2008: 231) dapat diihat pada tabel 3 berikut:

Tabel 3.

\begin{tabular}{cc} 
Pedoman Interpretasi Koefisien Korelasi \\
\hline $\begin{array}{c}\text { Interval } \\
\text { Koefisien }\end{array}$ & $\begin{array}{c}\text { Tingkat } \\
\text { hubungan }\end{array}$ \\
\hline $0,00-0,199$ & Sangat Rendah \\
$0,20-0,399$ & Rendah \\
$0,40-0,599$ & Sedang \\
$0,60-0,799$ & Kuat \\
$0,80-1,000$ & Sangat kuat \\
\hline
\end{tabular}


Aturan yang digunakan untuk menginterpretasi data adalah apabila $r$ hitung lebih besar dari $r$ tabel maka dapat disimpulkan korelasinya adalah signifikan sehingga hasil penelitian dapat digeneralisasikan. Apabila $r$ hitung kurang dari $r$ tabel maka korelasinya tidak signifikan, sehingga hasilnya tidak dapat digeneralisasikan.

\section{PEMBAHASAN}

Penelitian yang dilakukan ini bertujuan untuk mengetahui korelasi antara motivasi belajar dengan prestasi belajar peserta didik kelas $\mathrm{V}$ SD Negeri Jatisarono. Teknik pengambilan data menggunakan angket dan dokumentasi. Angket digunakan untuk mengambil data motivasi belajar sedangkan dokumentasi untuk mengambil data prestasi belajar peserta didik. Dokumentasi disini berupa nilai raport peserta didik kelas V SD Negeri Jatisarono semester 1 tahun ajaran 2018/2019. Kemudian untuk mengetahui korelasi antara motivasi belajar dan prestasi belajar digunakan teknik analisis korelasi product moment.

Hasil angket motivasi belajar peserta didik kelas V SD Negeri Jatisarono diperoleh bahawa skor terendah adalah 65, skor tertinggi adalah 102, mean 81,90, dan simpangan baku/ standar deviasi 10,66 dari keseluruhan responden. Responden dengan kategori rendah sebanyak 3 peserta didik dengan persentase $15 \%$, responden dengan kategori sedang sebanyak 13 peserta didik dengan persentase $65 \%$, dan responden dengan kategori tinggi sebanyak 4 peserta didik dengan persentase $20 \%$.

Kesimpulannya bahwa motivasi belajar matematika peserta didik kelas V SD Negeri Jatisarono sebagian besar berada pada kategori sedang dengan persentase $65 \%$. Dengan motivasi pada kategori sedang yang ada di SD Negeri Jatisarono maka secara tidak langsung menunjukkan bahwa ada indikator yang perlu ditingkatkan, supaya motivasi dalam kategori sedang ini dapat berubah menjadi kategori tinggi. Secara rinci dapat dilihat pada tabel 4 berikut.

Tabel 4.

Motivasi Belajar

\begin{tabular}{ccc}
\hline Skala & Frekuensi & Persen \\
\hline Tinggi & 4 & 20,0 \\
$(\mathrm{X}>92,55)$ & & \\
Sedang & 13 & 65,0 \\
$(71,25<\mathrm{X} \leq$ & & \\
$92,55)$ & & \\
Rendah & 3 & 15,0 \\
$(\mathrm{X} \leq 71,25)$ & & \\
$\quad$ Total & 20 & 100,0 \\
\hline
\end{tabular}

Secara lebih jelasnya dapat dilihat diagram berikut ini. 


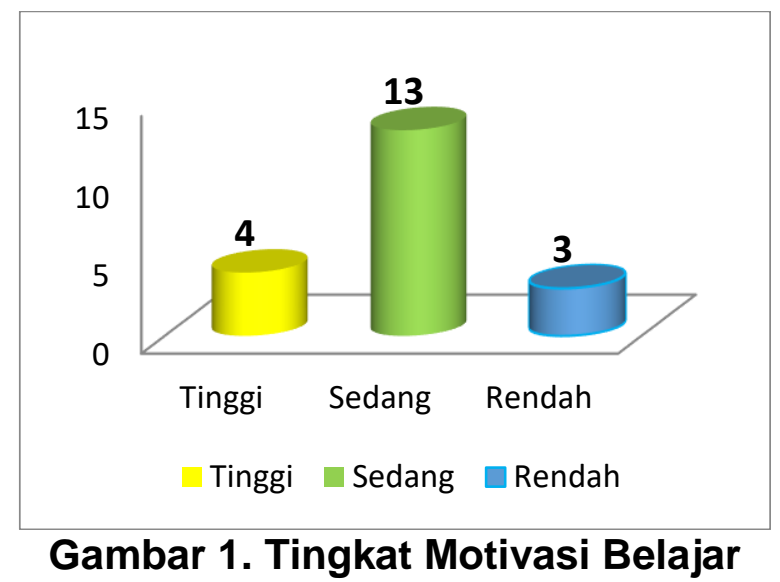

Pada data variable kedua yaitu prestasi belajar matematika didapatkan dari dokumentasi guru kelas $\mathrm{V}$ berupa nilai raport Matematika semester 1 peserta didik kelas V SD Negeri Jatisarono Nanggulan Kulon Progo tahun ajaran 2018/2019. Jumlah responden penelitian adalah 20 peserta didik. Responden dengan kategori rendah sebanyak 0 peserta didik dengan persentase $0 \%$, responden dengan kategori sedang sebanyak 17 peserta didik dengan persentase $85 \%$, dan responden dengan kategori tinggi sebanyak 3 peserta didik dengan persentase $15 \%$. Sehingga dapat disimpulkan bahwa prestasi belajar matematika peserta didik kelas V SD Negeri Jatisarono sebagian besar berada pada kategori sedang dengan persentase $85 \%$. Secara rinci dapat dilihat pada tabel 5 berikut.

\section{Tabel 5.}

Prestasi Belajar

\begin{tabular}{ccc}
\hline Skala & Frekuensi & Persen \\
\hline Tinggi & 3 & 15,0 \\
$(\mathrm{X}>87,03)$ & & \\
Sedang & 17 & 85,0 \\
$\begin{array}{c}(74,97<\mathrm{X} \leq \\
87,03)\end{array}$ & & \\
Rendah & 0 & 0,0 \\
$(\mathrm{X} \leq 74,97)$ & & \\
Total & 20 & 100,0 \\
\hline
\end{tabular}

Secara diagram dapat dilihat sebagai berikut.

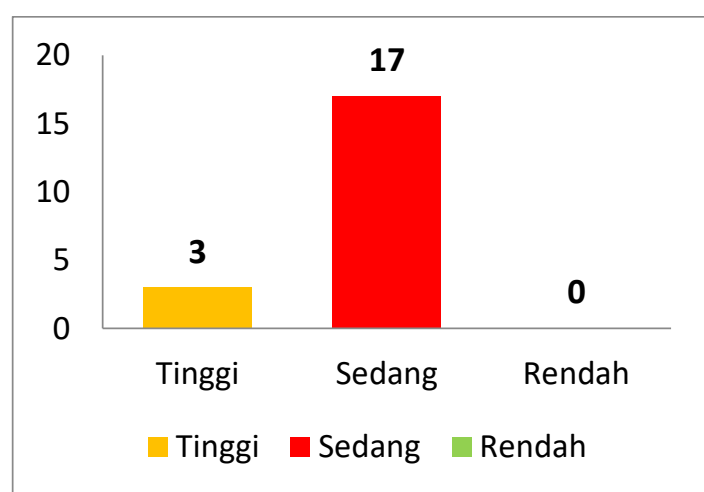

Gambar 2. Prestasi Belajar Matematika 
Uji prasyarat analisis meliputi uji normalitas dan uji linearitas. Uji normalitas dilakukan untuk mengetahui apakah variable dalampenelitian ini berdistribusi normal atau tidak. Pengujian normalitas variable ini menggunakan Kolmogorov-Smirnov yang dalam proses perhitungannya menggunakan bantuan program SPSS $v .18$ for windows. Kriteria yang digunakan yaitu jika taraf signifikansi lebih besar dari $5 \%(p>0,05)$ maka data dinyatakan berdistribusi normal.

Hasil interpretasi data dari hasil uji normalitas variabel motivasi belajar didapatkan nilai signifikansi sebesar 0,809 . Hasil tersebut apabila dibandingkan dengan $\alpha=0,05$ maka nilai $0,809>0,05$ yang artinya bahwa data berdistribusi normal. Kemudian hasil interpretasi data variable prestasi belajar didapatkan nilai signifikansi sebesar 0,197. Nilai ini apabila dibandingkan dengan $\alpha=0,05$ maka nilai $0,197>0,05$ disini memiliki arti data berdistribusi normal. Sehingga dapat dikatakan bahwa kedua variable dalam penelitian ini semua berdistribusi normal.

\section{Pengujian}

menggunakan analisis korelasi product moment. Interpretasi data hasil analisis korelasi dengan bantuan program SPSS for windows didapat angka korelasi antara variabel motivasi belajar $(X)$ dengan variabel prestasi belajar $(\mathrm{Y})$. Koefisien korelasi ( $r$ hitung) sebesar 0,493 . Sedangkan nilai $r$ tabel pada taraf signifikan $5 \%$ dimiliki peserta didik maka akan semakin tinggi pula prestasi belajar yang akan dicapai. Begitu pula sebaliknya semakin rendah motivasi yang dimiliki oleh peserta didik makan akan semakin rendah pula prestasi belajar yang akan dicapai, dan apabila dan $N=20$ adalah sebesar 0,360. Berdasarkan hasil analisis tersebut terlihat bahwa nilai $r$ hitung lebih besar dari nilai $r$ tabel $(0,493>0,360)$ dengan demikian $\mathrm{Ho}$ ditolak dan $\mathrm{Ha}$ diterima.

Jadi, dapat disimpulkan bahwa ada hubungan yang positif dan signifikan antara motivasi belajar dengan prestasi belajar pada mata pelajaran matematika peserta didik kelas V SD Negeri Jatisarono tahun ajaran 2018/2019.

Hasil dari penelitian ini sejalan dengan penelitian yang dilakukan oleh Hamdu (2011: 85) yang menyatakan bahwa motivasi belajar mempengaruhi prestasi belajar dengan tingkat interprestasi reliabilitas sebesar $48,1 \%$. Dengan kata lain motivasi belajar sangat berpengaruh kuat terhadap prestasi belajar yang akan dicapai

Hubungan antara motivasi belajar dengan prestasi belajar sesuai dengan pendapat dari Dalyono (2012: 55) yang menyatakan bahwa berhasil atau tidaknya seseorang guru dalam proses pembelajaran disebabkan oleh beberapa faktor yang mempengaruhi pencapaian prestasi belajar yaitu faktor internal dan faktor eksternal. Salah satu faktor internal tersebut adalah motivasi.

Berdasarkan kesimpulan dari penelitian ini, secara teoritis motivasi belajar dengan prestasi belajar sangat berkaitan erat atau bisa dikatakan berbanding lurus. Artinya yaitu semakin tinggi motivasi belajar yang

motivasi yang dimiliki adalah sedangsedang saja maka prestasi belajar juga akan sedang-sedang saja.

Dari konseptual tersebut maka gambaran yang dapat di lihat berdasarkan hasil penelitian ini sesuai dengan teori. Hal ini terlihat jelas 
dalam data yaitu subjek dalam penelitian ini secara garis besar memiliki motivasi belajar yang sedang. Kemudian kita lihat dari data prestasi, belajar yang dicapai dari subjek penelitian ini secara garis bersar juga pada taraf sedang.

Penelitian ini sudah dilakukan oleh peneliti secara optimal, akan tetapi masih terdapat keterbatasaketerbatasan dari peneliti. Keterbatasan tersebut antara lain adalah belum mampunya peneliti meneliti keseluruhan faktor baik internal ataupun eksternal. Peneliti hanya mengambil satu faktor saja yaitu motivasi belajar.

\section{SIMPULAN}

Berdasarkan hasil penelitian serta analisis data dan pembahasan maka dapat ditarik kesimpulan bahwa ada hubungan yang positif dan signifikan antara motivasi belajar dan prestasi belajar matematika kelas $\mathrm{V}$ SD Negeri Jatisarono Kecamatan Nanggulan tahun ajaran 2018/2019. Implikasi dari penelitian ini maka diharapkan peranan guru atau pendidik untuk bias meningkatkan motivasi belajar peserta didiknya. Supaya tujuan pembelajaran atau prestasi belajar peserta didik dapat maksimal.

\section{DAFTAR PUSTAKA}

Arikunto, S. (2006). Prosedur Penelitian suatu Pendekatan Praktik. Jakarta: PT. Rineka Cipta.

Azwar, S. (2010). Metode Penelitian. Yogyakarta: Pustaka Belajar.

Bakar, R. (2014). The Effect Of Learning Motivation On Student's Productive competencies In Vocational High School, West Sumatra. International Journal of Asian Social Science. 4(6):722-732.

Dalyono, M. (2012). Psikologi Pendidikan. Jakarta: Rineka Cipta.

Departemen Pendidikan Nasional. (2003). Undang-undang Republik Indonesia Nomor 20
Rekomendasi untuk penelitian selajutnya yaitu faktor-faktor yang mempengaruhi prestasi belajar sangatlah banyak tidak hanya motivasi. Untuk itu mungkin dapat dilakukan penelitian yang lain untuk mengetahui hubungan dari faktorfaktor lainnya terhadap prestasi belajar. Supaya dapat sebagai acuan teoritis faktor mana yang memiliki hubungan sangat tinggi dengan prestasi belajar. 
Sugiyono. (2008). Metode Penelitian Kuantitatif Kualitatif dan R\&D. Bandung: Alfabeta.

Susanto, A. (2013). Teori Belajar dan Pembelajaran di Sekolah Dasar. Jakarta: PT. Fajar Interpratama Mandiri.

Siregar, N.R. (2017). Persepsi siswa pada pelajaran matematika: studi pendahuluan pada siswa yang menyenangi game. Prosiding Temu IImiah X Ikatan Psikologi Perkembangan Indonesia. Diakses tanggal 17 Februari 2020 pukul 07:11 WIB dari http://jurnal.unissula.ac.id/index. php/ippi/article/view/2193.

Supardi \& Leonard. (2010). Pengaruh konsep diri, sikap siswa pada matematika, dan kecemasan siswa terhadap hasil belajar matematika.Cakrawala

Pendidikan, XXIX(3): 341-352 